\section{Covid-19: People are gathering again, but can crowds be made safe?}

chrisbaraniuk@gmail.com Cite this as: BMJ 2020;371:m3511 http://dx.doi.org/10.1136/bmj.m3511 Published: 02 October 2020

\section{The human desire to gather is a deeper behavioural need than we might expect. Chris Baraniuk examines why and how we might factor this into the pandemic response}

\section{Chris Baraniuk freelance journalist}

When lockdowns were imposed to control the spread of covid-19, it was immediately obvious that people would miss the close friends and family members who they were unable to visit. It was less obvious that people would also miss the hordes in their local shopping centre, queuing for a big match, or jostling with strangers to order a drink at the bar.

"We're used to engaging in gatherings, it's part of how we live and we're now being told we can't do that," says Linda Bauld, a behavioural scientist and professor of public health at the University of Edinburgh.

But failing to curtail this part of life has negative consequences during a pandemic.

"Right now, in places like the US, the epidemic is largely driven by people's behaviour and their social attitudes to the epidemic," says Lee Riley, head of infectious diseases and vaccinology at the University of California, Berkeley. The spread of covid-19 in New Orleans was linked to Mardi Gras celebrations in February and a conference in Boston the same month has been associated with 2000 cases. Yet many in southern US states remain eager to return to crowded events such as American Football games despite the virus still spreading.

And it's not just in the US. In May, authorities were compelled to shut down Seoul's clubs and bars for a second time after dozens of cases were linked to an infected man who visited a string of busy venues in the city. Similar clusters of infection in Tokyo were also linked to nightclubs and bars.

\section{Behavioural problems}

It may seem to beggar belief that people would take such risks during a pandemic. Understanding the root of this behaviour is the first step.

Jonathan Kanter, a psychologist at the University of Washington, says there are roughly three levels of social connection that humans need in order to feel mentally healthy: one or two intimate relationships such as a romantic partner or very close friend; membership of small social units such as families or friendship circles; and a connection to larger and more diffuse groups such as ethnic groups, a feeling of patriotism, fans of a football team, or crowds that attend large outdoor events, for example.

With family visits and social bubbles now in place, it's the last one that's most challenged by our current situation. "We feel a sense of membership among such groups when we find ourselves in crowds," says Kanter. "It feels healthy and meaningful and life affirming to be with other human beings in crowds-we're built by nature to crave that."
It's well established that group membership is psychologically desirable-that's one premise of Henri Tajfel's social identity theory ${ }^{1}$ first put forward in the 1970s. The sense of belonging to a group could be established in many ways but one route is through mixing in a like minded crowd.

During the pandemic, many people have faced extended periods of loneliness, which has heightened their desire to meet with others. Mental health problems such as anxiety and depression that have been associated with lockdowns could be exacerbated by feelings of continuing isolation or being excluded from wider society.

The craving for gathering affects adherence to social distancing, and attitudes also vary depending on demographic. A study by researchers at Johns Hopkins University published in June found that men were less inclined to think keeping a safe distance was important than women, despite being at greater risk from covid-19. ${ }^{2}$ Other research has suggested that young people-who are less likely to die from the virus but who may still transmit it-were more likely to have socialised with friends recently compared with older adults. ${ }^{3}$

\section{Virtual, not actual}

People could hardly be expected to simply give up gatherings entirely, says Kanter. Beyond socialising at entertainment events, there are political demonstrations and religious gatherings to take into account. Authorities are learning that they can't just cancel assemblies entirely. People will continue to seek them out and clamour for the reopening of sports stadiums or turn to illicit options such as illegal raves.

What we need, says Kanter, is to develop safe and fulfilling alternatives to grouping together in densely packed crowds. Two researchers alluded to this in March in the journal Travel Medicine and Infectious Disease. ${ }^{4}$ They anticipated that the Hajj

pilgrimage-generally considered the world's largest human gathering with around 2.5 million attendees annually-would be suspended this year because of the pandemic. "A means for Muslims to fulfil their rights in the future, either personally or even by proxy, need to be announced," the authors wrote.

In the end, the 2020 Hajj went ahead ${ }^{5}$ but with far fewer attendees-a mere 1000. The hundreds of thousands of pilgrims not able to attend in person were instead offered a digital substitute-a "virtual Hajj" similar to a video game. ${ }^{6}$

Digital alternatives are now common-the past few months have seen fake crowd noise added to sports broadcasts and the rise of virtual raves. Perhaps 
you've taken part in a Zoom pub quiz? But group video calls may worsen some participants' moods, particularly if they feel forced to join a call. "Our minds are together when our bodies feel we're not," Gianpiero Petriglieri, an associate professor at Insead Business School told the BBC, ${ }^{7}$ "that dissonance, which causes people to have conflicting feelings, is exhausting."

\section{The great public experiment}

Physically gathering together will always be preferable to some. The good news is that the risks can be managed. In the nine months since SARS-CoV-2 emerged we have learnt much about the transmission of the virus, which has improved our understanding about which gatherings may be considered safer than others.

There has been much discussion around "droplet versus aerosol” transmission-whether the virus is more infectious if it sticks to heavier moisture droplets produced when people sneeze or cough, or if it is spread by floating on tiny particles emitted when they breathe. "There's no hard and fast dividing line," says Michael Klompas, professor of population health at Harvard University, "people could produce both." Although debate over the details continues, the current consensus is that wearing a mask and distancing at least one metre or more from one another definitely has a protective effect, particularly if the space you are in is enclosed and you are there for a prolonged period (generally considered to be 15 minutes or more). ${ }^{8}$

Because most clusters of covid-19 transmission have been associated with indoor activities, ${ }^{9}$ outdoor events have been increasingly touted. A recent article in The $B M J^{10}$ suggested that high occupancy events in outdoor, well ventilated areas may be extremely low risk so long as people are not bunched together for long periods and are not shouting or speaking without facemasks.

By taking the specifics of crowded scenarios into account, it may be possible to gauge the risk of large gatherings. Researchers in Leipzig have set up experiments to study attendance and distancing measures at a small, experimental indoor concert. ${ }^{11}$ The hall hosted 1400 people, all of whom had tested negative for covid-19 and wore tracking devices that showed when they came into close contact with others and for how long.

In reopening college sports venues for the start of the academic year, some US universities are considered limiting attendance at a stadium to, say, $25 \%$ of the maximum capacity. Some have argued, however, that this is still too high. With sports, why not start without any fans at all, as German and English football leagues have done, and gradually introduce several thousand mask wearing fans at a time ${ }^{12}$

Nobody knows how problematic mass gatherings will prove to be. Ultimately, these events are huge public experiments. ${ }^{13}$ And despite the thousands of willing participants, there is still no universally agreed protocol for organising them.

Competing interests: I have read and understood BMJ policy on declaration of interests and have no relevant interests to declare.

Commissioned, not peer reviewed.

Haslam SA, Jetten J, Postmes T, Haslam C. Social identity, health and well-being: an emerging agenda for applied psychology. Appl Psychol

2009;58:1-23doi: 10.1111/j.1464-0597.2008.00379.x.

2 Papageorge NW, Zahn MV, Belot M, et al. Socio-demographic factors associated with self-protecting behavior during the covid-19 pandemic. Institute of Labor Economics. June 2020 www.iza.org/publications/dp/13333/socio-demographic-factors-associated-with-self-protectingbehavior-during-the-covid-19-pandemic.
3 Morin R. Young Americans less likely to social distance as coronavirus cases continue to rise, survey says. USA Today. 26 June 2020. https://eu.usatoday.com/story/news/politics/2020/06/26/coronavirus-young-americans-less-likely-social-distance/3257513001.

4 Ahmed QA, Memish ZA. The cancellation of mass gatherings (MGs)? Decision making in the time of COVID-19. Travel Med Infect Dis 2020;34:101631.

doi: 10.1016/j.tmaid.2020.101631 pmid: 32184129

5 Karadsheh J, Qiblawi T. “Unprecedented” Haji begins—with 1000 pilgrims, rather than the usual 2 million. CNN Travel. 29 July 2020. https://edition.cnn.com/travel/article/hajj-2020-coronavirusintl/index.html.

6 Alsherebi M. Virtual Hajj is a painful interval-but also Islam's most global moment yet. Newsweek. 24 June 2020. www.newsweek.com/virtual-hajj-global-islam-equal-rich-poor-covid-1513044.

7 Jiang M. The reason Zoom calls drain your energy. BBC. 22 April 2020. www.bbc.com/worklife/article/20200421-why-zoom-video-chats-are-so-exhausting.

8 Centers for Disease Control and Prevention. Case investigation and contact tracing guidance. 2020. www.cdc.gov/coronavirus/2019-ncov/php/contact-tracing/contact-tracing-plan/appendix.html.

9 Qian H, Miao T, Liu L, Zheng X, Luo D, Li Y. Indoor transmission of SARS-CoV-2. MedRxiv[Preprint]. 2020. www.medrxiv.org/content/10.1101/2020.04.04.20053058v1.

10 Jones NR, Qureshi ZU, Temple RJ, Larwood JPJ, Greenhalgh T, Bourouiba L. Two metres or one: what is the evidence for physical distancing in covid-19?BMJ2020;370:m3223. doi: 10.1136/bmj.m3223 pmid: 32843355

11 Noack R. Why German researchers held a large indoor concert during the pandemic. Washington Post. 24 August 2020. www.washingtonpost.com/world/2020/08/24/why-german-researchersheld-large-indoor-concert-during-pandemic.

12 Sapakoff G. Sapakoff: A fair plan for Clemson, South Carolina football attendance. Post and Courier. 23 August 2020. www.postandcourier.com/columnists/sapakoff-a-fair-plan-for-clemsonsouth-carolina-football-attendance/article_c60bb172-e2db-11ea-8307-5751bc73e955.html.

13 Perez JJr. Friday night frights: the South braces for fall football crowds. Politico 2020. www.politico.com/news/2020/08/25/arkansas-high-school-football-coronavirus-401857. 